\section{Changing Attitudes to Housing and Residential Location in Cities: The Cultural Clash and the Greyfield Solution}

\section{Introduction}

The evolution of Australia's urban residential fabric for much of the twentieth century was characterised by suburbanisation: continuous centrifugal expansion of the city in rings of low-density housing in greenfield estates on the urban fringe. This has led to population densities of the five largest capital cities as amongst the lowest in the world (Loader, 2016). Underpinning this pattern of residential development, especially for the latter half of the twentieth century, was a regime comprising a conventional, risk-averse residential-property industry, firmly tied to a greenfield model, aligned to metropolitan governments' continued support of 'suburban city' planning strategies and an auto industry that promoted cardependent urban sprawl. Greenfield developments offered households affordable access to house-and-land packages with private front- and backyards in a 'garden city' environment. This constituted the Australian dream, especially for the traditional nuclear family of that era. A review of housing-preference studies undertaken up to the early 1990s confirms this, with all published surveys showing that approximately $90 \%$ of all 
capital-city residents consistently nominated detached housing as the favoured dwelling type (Wulff, 1993).

Late-twentieth-century forces were challenging the sustainability of continued urban sprawl as a means of accommodating population growth. Significant shifts in demographics, lifestyles, and urban economics were signalling a need to reconsider how cities were being planned, with increasing calls for urban consolidation, more-compact cities, and greater variety in housing provision (Newman \& Kenworthy, 1999; Newton, 2000). Gentrification of low-priced inner-city residential property had begun in the late 1970s, initiated by households who preferred an 'urban' living environment, marking the beginning of the end for inner-city depopulation (Newton \& Thomson, 2017). Significant reurbanisation and densification of the inner suburbs was to follow. Similar patterns happened in all automobile-dependent cities across the world, particularly in the twenty-first century as knowledge-economy jobs and more-urban environments became valued for their higher residential amenity and accessibility (Brotchie et al., 1987; Newman \& Kenworthy, 2015; Florida, 2010).

As these inner suburbs gentrified, the existing residents opposed the changes in and densification of their neighbourhoods (Huxley, 2001), leading to the formation of 'Save our Suburbs' movements involving local communities banding together to resist what they considered 'overdevelopment' and urban designs that changed 'neighbourhood character'. Transitioning from suburban to urban fabrics via more intensive forms of urban infill represented a challenge to residents of established, more accessible suburbs to share their higher amenity space. During this period, housing in Australia's largest cities was also becoming increasingly unaffordable, and research indicated that an increasing proportion of residents surveyed by the Grattan Institute in Sydney and Melbourne, where property prices were highest, indicated they would prefer living in medium-density housing (Kelly et al., 2011). Results from this study (Table 6.1) show that from a preferences perspective, $40 \%$ of Sydney respondents and 38\% of those from Melbourne favoured mediumdensity housing; if high-density housing is included, the preference for density goes up to 60\% in Sydney and 52\% in Melbourne. For most of the twentieth-century, household surveys showed that preferences for 
Table 6.1 Dwelling preferences versus existing dwelling stock-Sydney and Melbourne

\begin{tabular}{|c|c|c|c|c|c|c|}
\hline \multirow[b]{2}{*}{ Location } & \multirow{2}{*}{$\begin{array}{l}\text { Population } \\
\text { preference \% } \\
\text { Existing (2006) } \\
\text { stock \% }\end{array}$} & \multicolumn{5}{|c|}{ Dwelling type } \\
\hline & & Detached & $\begin{array}{l}\text { Semi- } \\
\text { detached }\end{array}$ & $\begin{array}{l}\text { Up to } 3 \\
\text { storeys }\end{array}$ & $\begin{array}{l}4+ \\
\text { storeys }\end{array}$ & Total \\
\hline Sydney & Preference & 41 & 25 & 15 & 20 & 100 \\
\hline Sydney & Stock & 62 & 12 & 16 & 10 & 100 \\
\hline Melbourne & Preference & 48 & 26 & 12 & 14 & 100 \\
\hline Melbourne & Stock & 72 & 12 & 13 & 3 & 100 \\
\hline
\end{tabular}

Source: Extracted from Kelly et al. (2011)

higher density living rarely approached 20\% (Wulff, 1993). This is a remarkable change in urban culture in Australia and a huge political dilemma in the planning profession, as all the strategic-planning documents began to recognise this significant increase in demand for wellplaced density, but the planning systems of control did not allow the demand to be met. The conservative property development and building and construction industries were also slow to respond to these shifts in preferences, a fact reflected in major lags in supply of medium-density dwellings (Kelly 2011; Kelly et al., 2011; Newton et al., 2017; again, see Fig. 1.2).

This chapter seeks to clarify the clash of attitudes and values that has emerged in Australian cities in relation to housing, and to find a solution through regenerative urban redevelopment of the middle suburbs.

\section{Greening the Greyfields Survey}

This section examines the responses to a September 2016 online survey of 2000 residents living in Sydney and Melbourne to a range of housing issues associated with the Greening the Greyfields project (see Newton et al., 2017 for more details of the survey). The focus of the survey was on understanding trends in community attitudes towards medium-density living and neighbourhood change (intensification) in an attempt to understand the clash in cultures outlined above, which is reducing the opportunities for urban regeneration and perpetuating urban sprawl. 


\subsection{Stated Preferences for Dwelling Type and Preferred 'Living Arrangement'}

In response to a question posed to those households who indicated that they were likely to move residence within the next 15 years ('What type of dwelling would you want to live in?'), Table 6.2 shows that close to $60 \%$ of residents in both Sydney and Melbourne favoured a detached house and yard. In the space of 30 years (approximately one generation), there has been a significant attitude shift in (unconstrained) housing preferences - towards embracing higher-density forms of living.

While there are overlapping demographics across the housing typologies, those with a stronger preference for medium-density housing tended to be older ( $>60)$, in smaller households, living alone or with adult children, favouring a smaller dwelling, and looking to relocate within the same locality they currently live in. Those looking to move into an apartment also revealed a distinctive demographic: either younger (under 30) or older (over 60), more likely to be currently renting, in a small, singleperson household or living with other adults, and with a preference for inner-city living and close to a park that can be used regularly. These data

Table 6.2 Preferred type of future dwelling for households indicating a plan to move within next 15 years

\begin{tabular}{|c|c|c|c|c|c|}
\hline & & & Sydney & Melbourne & Total \\
\hline \multirow{8}{*}{$\begin{array}{l}\text { What type of } \\
\text { dwelling } \\
\text { would you } \\
\text { want to live } \\
\text { in? }\end{array}$} & Detached, stand-alone & Count & 214 & 213 & 427 \\
\hline & $\begin{array}{l}\text { house with private back } \\
\text { and front yard }\end{array}$ & $\%$ & 59.8 & 58.8 & 59.3 \\
\hline & Semi-detached single or & Count & 58 & 75 & 133 \\
\hline & $\begin{array}{l}\text { two-storey (town house, } \\
\text { duplex, villa unit with } \\
\text { small amount of private } \\
\text { space at ground level at } \\
\text { either front or rear) }\end{array}$ & $\%$ & 16.2 & 20.7 & 18.5 \\
\hline & An apartment, flat, or unit & Count & 71 & 62 & 133 \\
\hline & & $\%$ & 19.8 & 17.1 & 18.5 \\
\hline & Retirement village/hostel & Count & 15 & 12 & 27 \\
\hline & & $\%$ & 4.2 & 3.3 & 3.8 \\
\hline \multirow[t]{2}{*}{ Total } & & Count & 358 & 362 & 720 \\
\hline & & $\%$ & 100 & 100 & 100 \\
\hline
\end{tabular}


Table 6.3 Preference for urban living arrangements

\begin{tabular}{|c|c|c|c|c|c|}
\hline & & & Sydney & Melbourne & Total \\
\hline \multirow[t]{3}{*}{$\begin{array}{l}\text { If you had to choose } \\
\text { between the three } \\
\text { living } \\
\text { arrangements } \\
\text { specified, which } \\
\text { would you prefer? }\end{array}$} & $\begin{array}{l}\text { Separate dwelling } \\
\text { with a garden in a } \\
\text { suburb where there } \\
\text { is poor public } \\
\text { transport }\end{array}$ & $\begin{array}{l}\text { Count } \\
\%\end{array}$ & $\begin{array}{l}432 \\
45.2\end{array}$ & $\begin{array}{l}452 \\
46.1\end{array}$ & $\begin{array}{l}884 \\
45.7\end{array}$ \\
\hline & $\begin{array}{l}\text { Medium-density } \\
\text { dwelling with no } \\
\text { garden, but close to } \\
\text { public transport }\end{array}$ & $\begin{array}{l}\text { Count } \\
\%\end{array}$ & $\begin{array}{l}435 \\
45.5\end{array}$ & $\begin{array}{l}448 \\
45.7\end{array}$ & $\begin{array}{l}883 \\
45.6\end{array}$ \\
\hline & $\begin{array}{l}\text { High-rise apartment } \\
\text { in CBD or } \\
\text { surrounding } \\
\text { inner-city } \\
\text { neighbourhood }\end{array}$ & $\begin{array}{l}\text { Count } \\
\%\end{array}$ & $\begin{array}{l}89 \\
9.3\end{array}$ & $\begin{array}{l}80 \\
8.2\end{array}$ & $\begin{array}{l}169 \\
8.7\end{array}$ \\
\hline Total & & $\begin{array}{l}\text { Count } \\
\%\end{array}$ & $\begin{array}{l}956 \\
100\end{array}$ & $\begin{array}{l}980 \\
100\end{array}$ & $\begin{array}{l}1936 \\
100\end{array}$ \\
\hline
\end{tabular}

began to reveal what was motivating this cultural shift towards density. A further set of questions enabled more insight.

Living arrangements were examined to see how much they extended beyond the dwelling to include the neighbourhood and wider (sub)urban context in which people lived. Three distinctive living arrangements were explored (Table 6.3). Responses revealed that combining locational context with housing type significantly boosted preference for mediumdensity housing when situated in established suburbs well served by public transport and accessible to jobs and services: $46 \%$ - equivalent to the level of stated preference for a residential property comprising a separate dwelling with garden and dependent on access to a private car.

The data from this part of the survey indicated that people are more readily attracted towards a more 'urban' housing environment if they are given a sense that the additionality of living there is significant. This additionality is well understood in housing-preference literature and forms the basis for comprehending urban housing markets. A survey in Perth of households who had bought into apartments showed that many had done so because of the sustainability benefits in the housing itself (increasingly being marketed) and in the lifestyles they could now live without 
car-dependence (Green \& Newman, 2017). COVID-19 has highlighted the increased importance of 'localism' and 'additionality' in relation to neighbourhood amenity and services.

\subsection{Exploring NIMBYism: Resident Perspectives on Neighbourhood Densification and Change}

The question is whether these shifts in dwelling preference have been reflected in residents' attitudes towards change in the built environments in their neighbourhoods. Seventy-one percent of the total sample of respondents $(N=1983)$ were 'aware of neighbourhood change in their locality', a percentage that was identical for the property owners $(N=1402)$ who were no more or no less sensitized to local urban change than renters. For the remainder of the analyses, focus centres on the property owner group since they constitute those residents capable of driving precinct-scale citizen-endorsed or initiated regeneration.

Table 6.4 reveals a high level of consistency in Sydney and Melbourne residents' attitudes to neighbourhood change that is associated with an increase in residential density. Less than $10 \%$ of residents in both cities considered it a good thing, but almost $40 \%$ responded that they

Table 6.4 Attitude to neighbourhood change

\begin{tabular}{|c|c|c|c|c|c|}
\hline & & & Sydney & Melbourne & Total \\
\hline \multirow{8}{*}{$\begin{array}{l}\text { How do you feel about the } \\
\text { change that this increase } \\
\text { in level of housing } \\
\text { development/density is } \\
\text { having on the } \\
\text { neighbourhood around } \\
\text { you? }\end{array}$} & I think it is a & Count & 46 & 47 & 93 \\
\hline & good thing & $\%$ & 6.8 & 6.4 & 6.6 \\
\hline & I understand & Count & 245 & 281 & 526 \\
\hline & $\begin{array}{l}\text { that it has to } \\
\text { happen }\end{array}$ & $\%$ & 36.4 & 38.5 & 37.5 \\
\hline & Neutral & Count & 72 & 83 & 155 \\
\hline & & $\%$ & 10.7 & 11.4 & 11.1 \\
\hline & I would prefer & Count & 310 & 318 & 628 \\
\hline & $\begin{array}{l}\text { less or no } \\
\text { change in } \\
\text { density of } \\
\text { housing }\end{array}$ & $\%$ & 46.1 & 43.6 & 44.8 \\
\hline \multirow[t]{2}{*}{ Total } & & Count & 673 & 729 & 1402 \\
\hline & & $\%$ & 100 & 100 & 100 \\
\hline
\end{tabular}


understood that it must happen, and just over $10 \%$ were neutral. Preference for less or no change sat around $45 \%$. This suggests that there is a capacity to accept change, but at present it is grudging and not strongly endorsed or embraced. NIMBYism remains a barrier to urban redevelopment.

There are interesting demographic differences between those households who thought change is a good thing or understand it has to happen and those who were neutral or preferred no change. The former group tended to be younger, recent movers into the locality, more likely to be renters, in predominantly adult only households, and more likely to have plans to move in the next few years, and to prefer inner-city locations. A review of community resistance in the Australian property-redevelopment context (Newton et al., 2020) indicates it has not moved much beyond a focus on individual project sites, and thus the literature has assumed that community resistance comes primarily from site-specific issues, which is not always the case. Often the externalities associated with a project (i.e., its impacts on local infrastructure, services, traffic, safety, and environment) are what raise the most objections. This suggests that the narrative for change and the benefits that well-designed regenerative development can bring to a suburb and its residents need to be better communicated to the stereotypical property-owning suburban households who prefer less development in their neighbourhoods. Demonstrating the additionality of GPR and communicating this to residents is the focus for Chap. 7.

\subsection{Exploring YIMBYism: Perspectives on Resident-led Residential Redevelopment}

The next 'planning for change' stage in the survey probed the extent to which property owners contemplating a future move were aware of or open to options of selling as a consortium of neighbours-becoming key actors in resident-enabled regenerative urban redevelopment. While not commonplace, examples of this are being reported together with the value uplift they achieve (Fig. 6.1). The survey revealed that one-quarter of Sydney respondents were open to consolidating property for sale with neighbours; this figure was even higher (39\%) for property they owned as an investment (Table 6.5). 


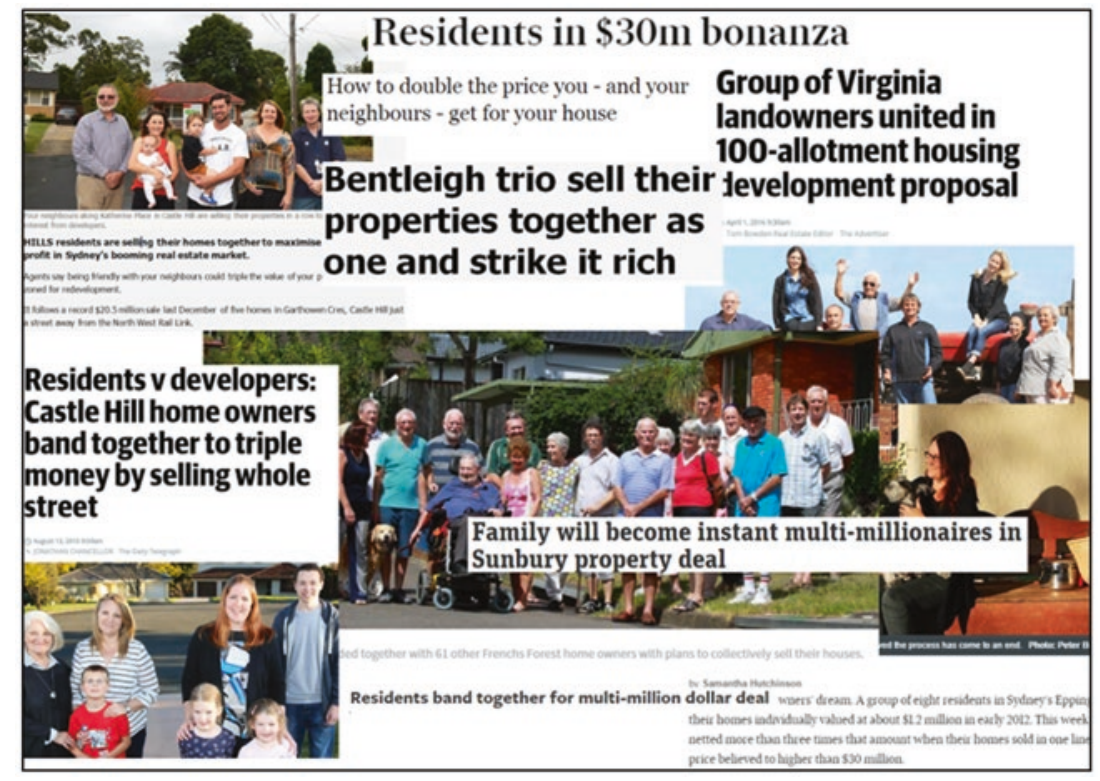

Fig. 6.1 Citizen-led lot consolidation in the suburban greyfields. (Source: Compiled by authors)

Table 6.5 Interest in the option of selling property as a consolidated redevelopment precinct in collaboration with neighbours

\begin{tabular}{|c|c|c|c|c|c|c|}
\hline \multirow{2}{*}{$\begin{array}{l}\text { Is selling property } \\
\text { jointly with } \\
\text { neighbours } \\
\text { something you would } \\
\text { consider? }\end{array}$} & \multicolumn{3}{|c|}{$\begin{array}{l}\text { Property currently owned } \\
\text { and occupied }\end{array}$} & \multicolumn{3}{|c|}{ Investment property } \\
\hline & Sydney & Melbourne & Total & Sydney & Melbourne & Total \\
\hline Yes \% & 25.4 & 16.9 & 21.1 & 39.1 & 27.4 & 33.9 \\
\hline No $\%$ & 48.1 & 57.1 & 52.7 & 39.8 & 53.1 & 45.7 \\
\hline Do not know \% & 26.5 & 26.0 & 26.2 & 21.1 & 19.5 & 20.4 \\
\hline Total \% & 100 & 100 & 100 & 100 & 100 & 100.0 \\
\hline Total N & 688 & 712 & 1400 & 161 & 128 & 289 \\
\hline
\end{tabular}

Several reports on negative community reaction to development include recommendations on overcoming resistance, such as positively framing developments for well-being (Holden, 2019), focusing on the local issues and local benefits (Petrova, 2014), and relying far more on the informal community structures than the formal municipal 
communications pathways in gaining community acceptance (Scally \& Tighe, 2015). These indicate the necessity to move beyond the current development proposal/complaint system, but are still not developed to the point where they can be readily and effectively implemented as YIMBY methods of practice. Engaging with residents, unpacking their views about the needs of a given locality, and introducing forms of additionality into a precinct can significantly reduce negative reaction to project proposals, and may even lead to support for development (Woodcock et al., 2016). This process is also far more likely to be supported by councillors and political stakeholders, as development purely for yield is typically not openly supported, but developments that satisfy both the community and municipal policy are. Consequently, demonstration of precinct additionality is a near necessity for scaled-up, medium-density construction in greyfields.

There would appear to be a capacity gap here: a deficit of trusted and qualified brokers capable of engaging greyfield residents with the appropriate financial and legal instruments necessary to progress 'kitchen table' discussions through to a positive outcome. This is rarely part of the business model in real-estate agencies, local government, or among property and construction companies.

\section{$3 \quad$ Meshing Housing Life Cycle and Household Life Cycle Analyses: A Step Towards Realising GPR}

The data from the above surveys show there is significant potential for urban regeneration at scale in greyfields, and that piecemeal knock-downrebuild of detached houses is not going to make the difference needed for creating the additionality required to achieve better public transport and better urbanism like that found in inner city walking and transit fabrics. So how can this be enabled?

As outlined in Chap. 1, greyfields are areas within cities with a high percentage of residential properties that have reached or are rapidly approaching the end of their life cycle and are currently occupied. The fact that they are occupied by different property owners represents a barrier to 
any straightforward lot-assembly process. A significant percentage of greyfield properties are also occupied by older residents (over the age of 55) - a cohort of the Australian population that is expected to double from 5.2 million (2012) to 14.1 million in 2062 (James et al., 2019). It is also a cohort that is confronting the need to consider their future residential and locational options. Over $60 \%$ of this age cohort are owner-occupiers (63\% for 55-59, rising to 72\% for 75-79; Whelan et al., 2019).

These facts provide a range of options for people in the middle suburbs: age in place, move to a retirement village, or downsize/rightsize to owning a smaller medium-density property or high-rise apartment. Several recent studies from the Australian Housing and Urban Research Institute (AHURI), such as those listed above and James et al. (2020), point to the multiple barriers to be overcome, prime among them being the financial cost of moving, but also a significant lack of coordinated and trusted information on seniors' housing options. There is a need to bring the information about housing options to those who are now facing the need to make some choices. The option of participating in GPR is never one of these unless particular residents in a neighbourhood such as featured in the stories in Fig. 6.1 are moved to participate in a lot-amalgamation initiative and create the option for a larger-scale redevelopment.

Urban planning at local and state government level needs to become more proactive in this space at both strategic and statutory levels. At a strategic planning level, bivariate spatial analyses of greyfield residential tracts demonstrating a combination of high redevelopment potential and high percentage of population over 55 years of age will highlight precincts where rezoning for GPR could have the best prospects (Fig. 6.2). At a statutory level, there needs to be realisation of community additionality for precinct-scale redevelopment if GPR is to be realised.

\section{Conclusion}

This chapter has shown that a major cultural shift is occurring in Australian cities, with over $50 \%$ of households now preferring to live in a more urban, amenity-rich location. The reason an increasing number of residents in Australian cities are primed and ready to move into higher-density living environments appears to be because they are increasingly embracing 


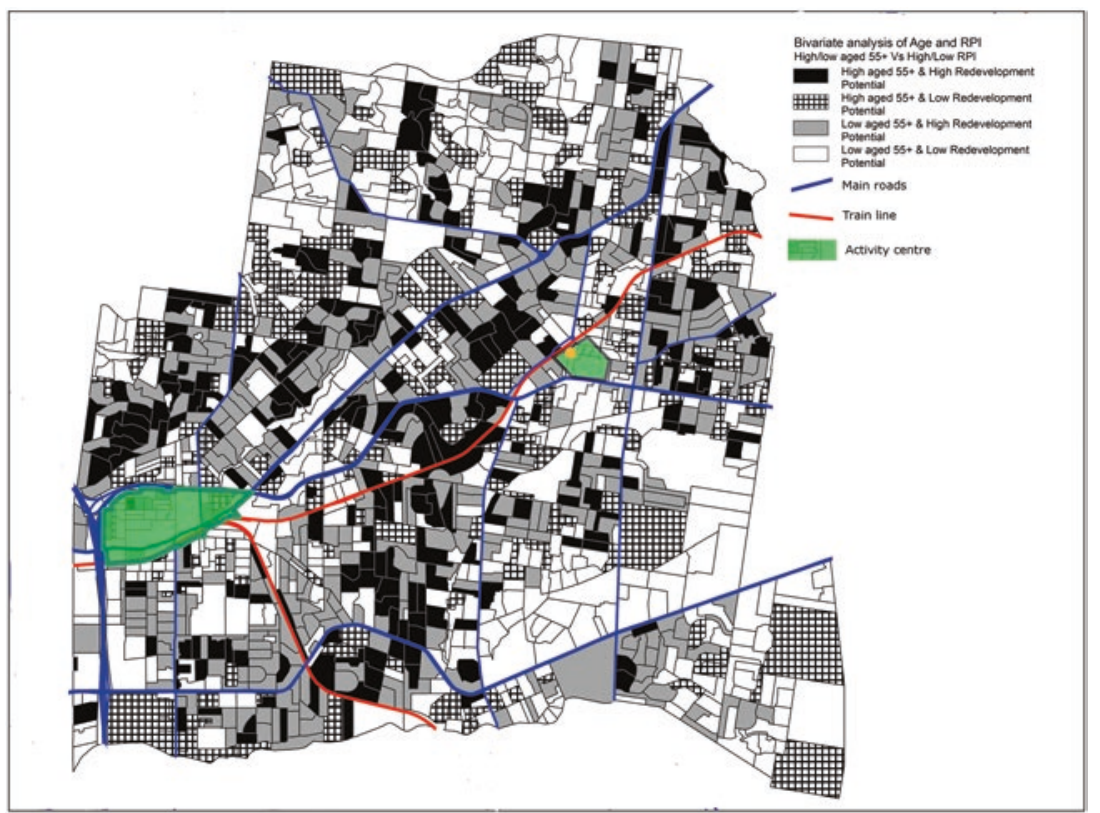

Fig. 6.2 Locating high residential redevelopment potential and high percentage of population aged over 55 in the (largely greyfield) City of Maroondah, Victoria. (Source: Derived by authors from Victorian Government spatial data)

an 'urban' rather than 'suburban' culture and lifestyle. The reality is, however, that the processes that are likely to enable this transition are simply not in place, as the inner suburbs are now beyond the means of most, unless high-density apartment living becomes the option. GPR in the middle suburbs represents a solution to providing the sought-after medium-density housing supply and amenity provision-in the right places. As Kelly et al. (2011, p. 2) have argued: 'We should not be afraid to shape our cities: otherwise we will risk them shaping us. But we should shape them in accordance with what Australians say they would choose'.

\section{References}

Brotchie, J., Hall, P., \& Newton, P. W. (1987). The transition to an information society. In J. F. Brotchie, P. Hall, \& P. W. Newton (Eds.), The spatial impact of technological change (pp. 435-451). Croom Helm and Methuen. 
Florida, R. (2010). The great reset: How new ways of living and working drive postcrash prosperity. Harper Collins.

Green, J., \& Newman, P. (2017). Demand drivers for medium density housing and the relative importance of sustainability attributes. Journal of Urban Research and Planning, 36(2), 201-214. https://doi.org/10.1080/0811114 6.2017.1295935

Holden, M. (2019). Bringing the neighbourhood into urban development in the interest of well-being. International Journal of Community Well-being 2019 (1), 137-155. https://doi.org/10.1007/s42413-018-0010-4.

Huxley, M. (2001). The suburbs strike back. In O. Yiftachel, J. Little, D. Hedgecock, \& I. Alexander (Eds.), The power of planning: Spaces of control and transformation (pp. 103-116). Kluwer.

James, A., Rowley, S., Stone, W., Parkinson, S., Spinney, A., \& Reynolds, M. (2019). Older Australians and the housing aspirations gap. AHURI Final Report 317. Australian Housing and Urban Research Institute.

James, A., Rowley, S., \& Stone, W. (2020). Effective downsizing options for older Australians. AHURI Report 325. Australian Housing and Urban Research Institute.

Kelly, J.-F. (2011). Getting the housing we want. Grattan Institute.

Kelly, J.-F., Weidmann, B., \& Walsh, M. (2011). The housing we'd choose. Grattan Institute.

Loader, C. (2016). Comparing the densities of Australian, European, Canadian, and New Zealand cities. Charting Transport. Retrieved July 14, 2017, from https://chartingtransport.com/2015/11/26/comparing-the-densitiesof-australianand-european-cities/

Newman, P., \& Kenworthy, J. (1999). Sustainability and cities: Overcoming automobile dependence. Island Press.

Newman, P., \& Kenworthy, J. (2015). The end of automobile dependenceMoving beyond car-based planning. Island Press.

Newton, P. (2000). Urban form and environmental performance. In K. Williams, E. Burton, \& M. Jenks (Eds.), Achieving sustainable urban form (pp. 46-53). E\&FN Spon.

Newton, P., \& Thomson, G. (2017). Urban regeneration in Australian cities. In P. Roberts, H. Sykes, \& R. Granger (Eds.), Urban regeneration: A handbook (Rev. ed., pp. 228-313). SAGE.

Newton, P., Meyer, D., \& Glackin, S. (2017). Becoming urban: Exploring the capacity for a suburban-to-urban transition in Australia's low-density cities. Sustainability, 9(10), 1718. https://doi.org/10.3390/su9101718 
Newton, P., Glackin, S., Garner, L., \& Witheridge, J. (2020). Beyond small lot subdivision: Pathways for municipality-initiated and resident-supported precinct-scale medium-density residential infill regeneration in greyfield suburbs. Urban Policy and Research, 38(4), 338-356. https://doi.org/10.1080/ 08111146.2020 .1815186

Petrova, M. A. (2014). From nimby to acceptance: Towards a novel framework - VESPA - for organising and interpreting community concerns. Renewable ENERGY, 86, 1280-1294.

Scally, C. P., \& Tighe, J. R. (2015). Democracy in action?: NIMBY as impediment to equitable affordable housing siting. Housing Studies, 30(5), 5. https:// doi.org/10.1080/02673037.2015.1013093

Whelan, S., Atalay, K., Barrett, G., \& Edwards, R. (2019). Moving, downsizing, and housing equity consumption choices of older Australians. AHURI Report 321. Australian Housing and Urban Research Institute.

Woodcock, I., Wollan, S., \& Dovey, K. (2016). Would you like a code with that? Place-based planning and mapping neighbourhood fields of care. In R. Leshinsky \& C. Legacy (Eds.). Instruments of planning: Tensions and challenges for more equitable and sustainable cities (pp. 125-141). NY: Routledge.

Wulff, M. (1993). An overview of Australian housing and locational preference studies: Choices and constraints on the housing market. Urban Policy and Research, 11, 230-237.

Open Access This chapter is licensed under the terms of the Creative Commons Attribution 4.0 International License (http://creativecommons.org/licenses/ by/4.0/), which permits use, sharing, adaptation, distribution and reproduction in any medium or format, as long as you give appropriate credit to the original author(s) and the source, provide a link to the Creative Commons licence and indicate if changes were made.

The images or other third party material in this chapter are included in the chapter's Creative Commons licence, unless indicated otherwise in a credit line to the material. If material is not included in the chapter's Creative Commons licence and your intended use is not permitted by statutory regulation or exceeds the permitted use, you will need to obtain permission directly from the copyright holder.

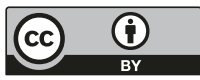

